\title{
Single-step purification of crotapotin and crotactine from Crotalus durissus terrificus venom using preparative isoelectric focusing
}

\author{
A.S. Aguiar ${ }^{1}$, \\ A.R. Melgarejo ${ }^{1}$, \\ C.R. Alves ${ }^{3}$ and \\ S. Giovanni-De-Simone ${ }^{2,3}$
}

\author{
${ }^{1}$ Divisão de Animais Peçonhentos, Instituto Vital Brazil, \\ 24230-340 Niterói, RJ, Brasil \\ ${ }^{2}$ Departamento de Biologia Celular e Molecular, \\ Universidade Federal Fluminense, 24001-970 Niterói, RJ, Brasil \\ ${ }^{3}$ Laboratório de Microseqüenciamento de Proteínas, \\ Departamento de Bioquímica e Biologia Molecular, \\ Instituto Oswaldo Cruz, FIOCRUZ, 21040-900 Rio de Janeiro, RJ, Brasil
}

\section{Correspondence \\ S. Giovanni-De-Simone \\ Departamento de Bioquímica e \\ Biologia Molecular \\ Instituto Oswaldo Cruz, FIOCRUZ \\ 21040-900 Rio de Janeiro, RJ \\ Brasil \\ Fax: 55 (021) 590-3495 \\ E-mail: dsimone@gene.dbbm.fiocruz.br \\ Research supported by CNPq and FIOCRUZ.}

Received January 2, 1995

Accepted November 4, 1996

\begin{abstract}
We describe the isolation of crotoxin, a presynaptic B-neurotoxin, as well as its subunits B (crotactine) and A (crotapotin) from lyophilized Crotalus durissus terrificus venom by a single-step preparative isoelectric focusing procedure. From $98 \mathrm{mg}$ of dried venom protein 20.1 $\mathrm{mg}$ of crotactine and $13.1 \mathrm{mg}$ of crotapotin were recovered in the first step of focalization and $4.2 \mathrm{mg}$ in a second run. These values correspond to $35.7 \%$ of the total venom protein applied. Crotactine separated in the 9.3-7.0 $\mathrm{pH}$ range (tubes 1-6) and crotapotin in the 1.8-2.8 $\mathrm{pH}$ range (tubes 15-19) and both were homogeneous by SDS-PAGE and N-terminal amino acid analysis. Crotactine, a 12-kDa protein, presented hemolytic and phospholipase $\mathrm{A}_{2}$ activity. Thus, using isoelectric focusing we simultaneously purified both toxins in high yields. This method can be used as an alternative for the purification and characterization of proteins from other snake venoms under conditions in which biological activity is retained.
\end{abstract}

Crotoxin is a presynaptic B-neurotoxin present in South American rattlesnake venoms (1). This toxin is a heterodimeric protein composed of noncovalently bound subunits: component $\mathrm{B}$, or crotactine, a basic protein having phospholipase $\mathrm{A}_{2}\left(\mathrm{PA}_{2}\right)$ activity, and component $\mathrm{A}$, or crotapotin, the acidic protein. Crotactine (B) presents moderate toxicity and crotapotin (A) is devoid of toxic or enzymatic activities. The addition of component $A$ apparently increases the toxicity of component B (2-4). The dissociation of the
Key words

- Crotalus durissus terrificus

- Crotactine

- Crotapotin

- Phospholipase $\mathrm{A}_{2}$

- Isoelectrofocusing

- Presynaptic B-neurotoxin subunits is reversible. It has been proposed that crotapotin functions as a chaperon molecule, preventing nonspecific binding of the phospholipase $A_{2}$ subunit of the toxin (5).

Although crotoxin was described in 1938 as the first rattlesnake venom protein to be isolated (6), its subunit composition was established only in 1978 (7) and the structure of the B-chain was only completed in 1990 $(8,9)$. The toxin is present in variable concentrations in rattlesnake venom and accounts for nearly $80 \%$ of total protein of Crotalus 
durissus collilineatus venom (1). Nevertheless its isolation as a homogeneous protein is tedious and time consuming and requires several chromatographic steps including gel filtration, ion-exchange chromatography and reverse-phase high performance liquid chromatography (HPLC) $(8,9)$.

Since this toxin may be a useful tool in electrophysiological studies (10) and contribute to the understanding of the different biologial effects of the $\mathrm{PA}_{2}$ enzyme subunit in different systems $(11,12)$, we developed a simple procedure for the isolation of the A and B subunits by isoelectrofocusing of the lyophilized intact venom in a single step using a Rotofor ${ }^{\circledR}$ apparatus.

This method is simpler and more rapid than the multiple chromatographic steps described in the literature and is suitable for preparation of mg quantities of both subunits in the same run.

Lyophilized venom of Crotalus durissus terrificus (Lot 01/90-3) was obtained by "milking" snakes maintained in the serpentarium of the Vital Brazil Institute. Lyophilized venom (116 mg containing $93 \mathrm{mg}$ of protein) was diluted to $20 \mathrm{ml}$ with $10 \mathrm{mM}$ Tris- $\mathrm{HCl}, \mathrm{pH}$ 6.5, and dialyzed overnight against the same buffer solution at $4^{\circ} \mathrm{C}$. The insoluble material was removed by centrifugation $\left(10,000 \mathrm{~g}, 30 \mathrm{~min}, 4^{\circ} \mathrm{C}\right)$ and $200 \mu \mathrm{l}$ of pH 3-10 ampholytes (Bio-Rad, Richmond, CA) was added to $20 \mathrm{ml}$ of the supernatant solution. The final volume was made up to $45 \mathrm{ml}$ with $10 \mathrm{mM}$ Tris- $\mathrm{HCl}$ buffer providing a final concentration of ampholyte equal to $0.44 \%$ and the sample was focused in a Rotofor chamber (Bio-Rad, Richmond, CA) using $300 \mathrm{~V}$ for $1 \mathrm{~h}, 400 \mathrm{~V}$ for $1 \mathrm{~h}$, and 500 $\mathrm{V}$ for $1 \mathrm{~h}$, and a limit of $12 \mathrm{~W}$. Twenty fractions were obtained after focusing, the $\mathrm{pH}$ of each was determined and the fractions were stored at $4^{\circ} \mathrm{C}$. Fractions $1-6(\mathrm{pH} 8.2$ to 9.3) and $15-19$ (pH 1.8 to 2.8) were pooled separately and $5.0 \mathrm{M} \mathrm{NaCl}$ was added to provide a final concentration of $1.0 \mathrm{M} \mathrm{NaCl}$, necessary for the removal of ampholytes by dialysis using tubing with a $3,000 \mathrm{Mr}$ cutoff, against $10 \mathrm{mM}$ citrate buffer, $\mathrm{pH} 4.5$, for $16 \mathrm{~h}$ at $4^{\circ} \mathrm{C}$, and stored frozen at $-10^{\circ} \mathrm{C}$ for further study. Protein concentration was determined by the method of Lowry et al. (13) using serum albumin as a standard.

Protein homogeneity was demonstrated by SDS-polyacrylamide gel electrophoresis (SDS-PAGE) using $15 \%$ polyacrylamide gels in Laemmli buffers (14) under reducing conditions.

Figure 1a shows a Coomassie blue-stained SDS-PAGE gel of the C.d.terrificus venom proteins isolated by Rotofor-IEF electrophoresis. A single band of approximately 12 $\mathrm{kDa}$ was observed in fractions 1-6 and a 9$\mathrm{kDa}$ band was observed in tubes 14-20. These fractions yielded 20.13 and $13.1 \mathrm{mg}$ of protein, respectively, corresponding to $35.7 \%$ of total applied venom proteins. Band A (acidic protein or crotapotin) was distributed from $\mathrm{pH} 1.8$ to $\mathrm{pH} 3.0$ while the band $\mathrm{B}$ (basic protein or crotactine) from $\mathrm{pH} 7.0$ to $\mathrm{pH}$ 9.3. The range of $\mathrm{pH}$ found for both proteins is within the range of $\mathrm{pH}(2.8-3.7$ and 7.8-9.2) reported after IEF by others $(5,7)$. The refractionation of the pooled tubes $7-9$ permitted the recovery of more than 4.2 $\mathrm{mg}$ of pure $12-\mathrm{kDa}$ protein, increasing the recovery of this protein to $24.33 \mathrm{mg}$. The spreading of the proteins during focusing may be attributed to different degrees of molecular glycosylation $(15,16)$ or $\mathrm{pI}$ microheterogeneity due the presence of molecular isoforms as suggested for other venom proteins (17).

In order to identify and investigate the biological activity of the isolated proteins, aliquots from several tubes were analyzed for hemolytic activity (18). Tubes 1-7 contained hemolytic activity but no hydrolysis could be observed with the material from tubes 14-20 (data not shown), thus showing that the basic compound (crotactine) presented $\mathrm{PA}_{2}$ activity and that the enzyme was still active after the isoelectrofocusing step. The identity of this basic $12-\mathrm{kDa}$ protein was 


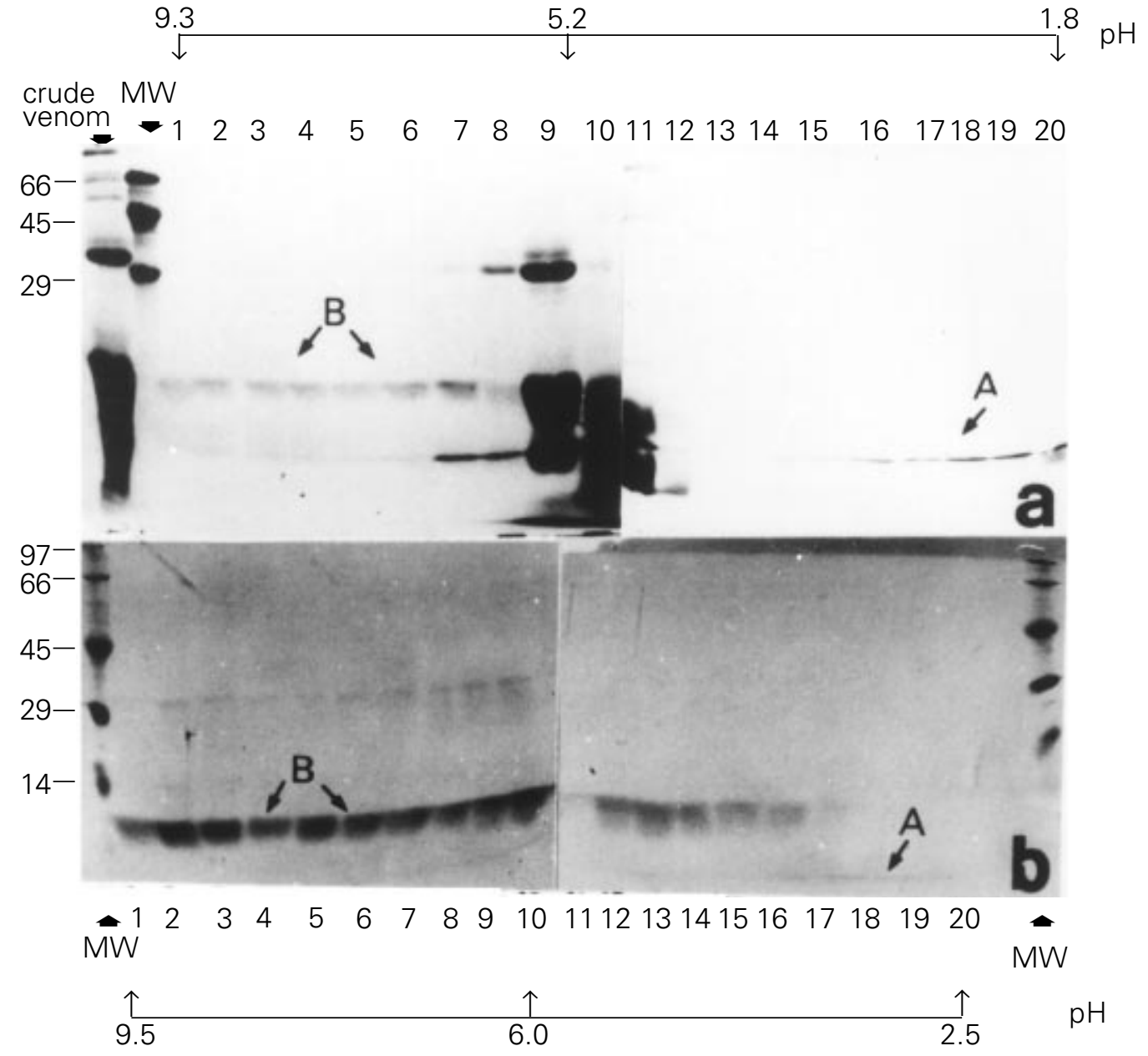

established by partial amino N-terminal sequencing using the automatic Edman degradation method and a Shimadzu PSQ-1 microsequencer (initial amount loaded, 100 pmol; initial yield, $32 \%$; repetitive yield, 92.3\%). The sequence of 10 aminoterminal residues, HLLQFNKMIK, is identical to that described for $\mathrm{PA}_{2}$ from C. d. terrificus (9).

Since the crotoxin chains are dissociated in the presence of urea, an attempt at fractionation was made using the same buffer containing $1 \mathrm{M}$ urea under the conditions described above (Figure 1, panel b). In this case, the amount of recovered protein (bands A and B) was 1.2-1.8-fold higher. However, a spreading of band B (crotactine) over pI 9.3-4.2 with traces of the $29-\mathrm{kDa}$ protein could be observed (Figure 1, panel b). The purification of both proteins in urea required more than two electrophoresis steps, making the method laborious and time consuming.

In comparison to methods commonly used for purification of crotactine (basic subunit) and crotapotin (acid subunit) proteins, the present method is simpler and requires less reagents and time. Only the Rotofor chamber equipment and ampholines are required. Using this method, which requires only dialysis, highly purified crotactine and crotapotin can be obtained in mg amounts from crude venom of $C$. durissus terrificus within about $4 \mathrm{~h}$. It should be possible to scale up the method to fractionate about $1 \mathrm{~g}$ of protein in each run.
Figure 1 - SDS-polyacrylamide $(15 \%)$ gel electrophoresis of the Crotalus durissus terrificus venom proteins fractionated in a Rotofor cell (fractions 1 to 20) without (pane a) and with (panel b) $1 \mathrm{M}$ urea. In Figure 1a, 16-26 $\mu \mathrm{g}$ of protein was applied to each lane except intact venom to which $25 \mu \mathrm{g}$ was applied. In Figure $1 \mathrm{~b}, 20-28 \mu \mathrm{g}$ of protein was applied to each lane. The gels were stained with Coomassie blue. On the left side of the figures the Mr values of the standard proteins [phosphorylase B $(97,400)$, bovine serum albumin $(66,000)$, ovalbumin $(45,000)$, carbonic anhydrase $(29,000)$ and lysozyme $(14,500)]$ are shown and the $\mathrm{pH}$ values determined after isoelectrofocusing are indicated above and below the figure. In the top panel, fractions 1 to 6 were combined to provide crotactine and fractions 15 to 19 contained crotapotin. A, The acidic protein crotapotin; B, the basic protein crotactine. 


\section{References}

1. Lennon BW \& Kaiser II (1990). Isolation of a crotoxin-like protein from the venom of a South American rattlesnake (Crotalus durissus collilineatus). Comparative Biochemistry and Physiology, 97B: 695-699.

2. Rubsamen $K$, Breithaupt $H$ \& Habermann E (1971). Biochemistry and pharmacology of the crotoxin complex. I. Subfractionation and recombination of the crotoxin complex. Naunyn-Schmiedeberg's Archives of Pharmacology, 270: 274-288.

3. Trivedi S, Kaiser II, Tanaka M \& Simpson LL (1989). Pharmacologic experiments on the interaction between crotoxin and the mammalian neuromuscular junction. Journal of Pharmacology and Experimental Therapeutics, 251: 490-496.

4. Breithaupt $H$, Rubsamen $K$ \& Habermann E (1974). Biochemistry analysis of crotapotin and the basic crotalus phospholipase A. European Journal of Biochemistry, 49: 333-345.

5. Stocker KF (1990). Medical Use of Snake Venom Proteins. CRS Press, Boca Raton, Ann Arbor, Boston, 66-78.

6. Slotta KH \& Fraenkel-Conrat HL (1938). Schlangengifte III. Mitteilung: Reinigung und Kristallisation des Klapperschlangengiftes. Bericht Deutsche Chemische Gesellschaft, 71: 1076-1081.
7. Fraenkel-Conrat $\mathrm{H}$, Jeng TW \& Hsiang $\mathrm{H}$ (1980). Biological activities of crotoxin and amino acid sequence of crotoxin B. In: Eaker D \& Wadstrom T (Editors), Natural Toxins. Pergamon Press, Oxford, 561567.

8. Aird SD, Kaiser II, Lewis RV \& Kruggel WG (1986). A complete aminoacid sequence for the basic subunit of crotoxin. Archives of Biochemistry and Biophysics, 249: 296-300.

9. Aird SD, Yates III JR, Martin PA, Shabanowitz J, Hunt DF \& Kaiser II (1990). The aminoacid sequence of the acidic subunit $\beta$-chain of crotoxin. Biochimica et Biophysica Acta, 1040: 217-224.

10. Araujo DAM \& Beirão PSL (1993). Effects of crotoxin on the action potential kinetics of frog skeletal muscle. Brazilian Journal of Medical and Biological Research, 26: 1111-1121.

11. Kouyoumdjian JA, Harris JB \& Johnson MA (1986). Muscle necrosis caused by the sub-units of crotoxin. Toxicon, 24: 575-583.

12. Gopalakrishnakone P, Dempster DW, Hawgood BJ \& Elder HY (1984). Cellular and mitochondrial changes induced in the structure of murine skeletal muscle by crotoxin, a neurotoxin phospholipase $\mathrm{A}_{2}$. Toxicon, 22: 85-98.
13. Lowry $\mathrm{OH}$, Rosebrough NJ, Farr AL \& Randall RJ (1951). Protein measurement with Folin phenol reagent. Journal of Biological Chemistry, 193: 265-275.

14. Laemmli UK (1970). Cleavage of structural protein during the assembly of the head of bacteriophage T4. Nature, 227: 680-685.

15. Silveira $A M V$, Magalhães $A$, Diniz $C R$ \& De Oliveira EB (1989). Purification and properties of the thrombin-like enzyme from the venom of Lachesis muta muta. International Journal of Biochemistry, 21: 863-871.

16. Aguiar AS, Alves $C R$, Melgarejo A \& Giovanni De Simone S (1996). Purification and partial characterization of a thrombinlike/gyroxin enzyme from buschmaster (Lachesis muta rhombeata). Toxicon, 34: 555-565.

17. Aird SD, Kruggel WG \& Kaiser II (1991) Multiple myotoxin sequences from the venom of a single prairie rattlesnake ( $\mathrm{CrO}-$ talus viridis viridis). Toxicon, 28: 265-268.

18. Gutierrez JM, Avila C, Rojas E \& Cerdas L (1988). An alternative in vitro method for testing the potency of the polyvalent antivenom produced in Costa Rica. Toxicon, 26: 411-413. 